\title{
The Effect of Oral Isotretinoin on Bone Healing in Rabbit Rhinoplasty Model: An Experimental Study
}

\author{
Oral İsotretinoinin Tavşan Rinoplasti Modelinde Kemik Iyileșmesine Etkisi: Deneysel \\ Çalıșma
}

\author{
(1) Şahin Öğreden¹, (1) Hasan Deniz Tansuker1', (1) Funda Emre² \\ 1istanbul Bağcılar Training And Research Hospital, Clinic of Otolaryngology, Istanbul, Turkey \\ 2istanbul Bağcılar Training And Research Hospital, Clinic of Pathology, İstanbul, Turkey
}

\begin{abstract}
Introduction: Since the age at which rhinoplasty is frequently performed is also the age at which acne is frequently seen, a person may be a candidate for both this surgery and isotretinoin therapy. In this study, we aimed to investigate the effect of oral isotretinoin on bone healing in rabbit rhinoplasty model.

Methods: Twelve one-year-old New Zealand white rabbits (3-4 g, all male) were included in the study. The animals were divided into two groups as experimental $(n=6)$ and control group $(n=6)$. One $\mathrm{mg} / \mathrm{kg}$ oral isotretinoin and olive oil mixture was given each day orally to the experimental group starting from the surgery day. Lateral nasal osteotomy was performed starting from the distal end of the nasal bone. The rabbits were sacrificed 4 weeks later and the nasal bone specimens were sent for histopathological examination to evaluate bone healing between the groups. Bone healing was classified according to the grading described by Huddleston.

Results: Grade 1 bone healing was observed in four samples $(66.7 \%)$ and grade 2 healing was observed in two samples (33.3\%) in the study group. In the control group, three samples $(50 \%)$ had grade 2 bone healing and the other three samples $(50 \%)$ had grade 3 bone healing. The difference between the groups was statistically significant $(p=0.027)$.

Conclusion: Bone healing was found to be slower in the isotretinoin group than in the untreated group. Although there are studies in the literature reporting that isotretinoin has a positive effect on bone healing, we observed opposite results. Therefore, we think that more experimental and clinical studies are needed to clarify this effect.
\end{abstract}

Keywords: Isotretinoin, lateral nasal osteotomy, bone healing öz

Amaç: Burun estetiğinin sıklıkla yapıldığı yaş, aynı zamanda aknenin de sık görüldüğü yaș olduğundan, bir kişi hem bu ameliyat için hem de izotretinoin tedavisi için aday olabilir. $\mathrm{Bu}$ nedenle, çalıșmamızda tavşan rinoplasti modelinde oral izotretinoinin kemik iyileșmesi üzerine etkisini araștırmayı amaçlandık.

Yöntemler: On iki adet bir yașında Yeni Zelanda beyaz tavșanı (3-4 g, tümü erkek) çalıșmaya dahil edildi. Hayvanlar deneysel $(n=6)$ ve kontrol grubu olmak üzere iki gruba ayrıldı. Operasyon gününden itibaren deney grubuna her gün oral olarak $1 \mathrm{mg} / \mathrm{kg}$ oral izotretinoin ve zeytinyağı karıșımı verildi. Nazal kemiğin distal ucundan başlayan lateral nazal osteotomi yapıldı. Tavşanlar 4 hafta sonra sakrifiye edildi ve gruplar arasındaki kemik iyileşmesini değerlendirmek için nazal kemik örnekleri histopatolojik incelemeye gönderildi. Tavşanların kemik iyileşmesi, Huddleston tariflenen kemik iyileșme skoruna göre değerlendirildi.

Bulgular: Çalıșma grubundaki 4 örnekte $(\% 66,7)$ 1.derece kemik iyileşmesi ve 2 örnekte $(\% 33,3)$ 2. derece kemik iyileșmesi gözlendi. Kontrol grubunda ise 3 örnekte (\%50) 2. derece kemik iyileșmesi, diğer 3 örnekte (\%50) 3.derece kemik iyileşmesi mevcuttu. Gruplar arasındaki fark istatistiksel olarak anlamlıydı ( $p=0.027)$.

Sonuç: İotretinoin grubundaki kemik iyileșmesi, tedavi edilmemiş gruba göre daha yavaş bulundu. Literatürde izotretinoinin kemik iyileșmesi üzerinde olumlu etkisi olduğunu bildiren çalıșmalar olmasına rağmen, biz çalıșmamızda bunun karşıt sonuçlarını gözlemledik. Bu nedenle, bu etkiyi açıklığa kavușturmak için daha fazla deneysel ve klinik çalıșmaya ihtiyaç olduğunu düşünüyoruz.

Anahtar Kelimeler: İsotretinoin, lateral nazal osteotomi, kemik iyileșmesi 


\section{Introduction}

Rhinoplasty is a very common aesthetic surgery that has become more popular day by day. Lateral osteotomy, which is one of the most challenging stages of this surgery, can cause damage to the mucosa and periosteum enveloping the bone tissue (1). It is important to ensure adequate mobilization and not to damage soft and supporting tissues when performing osteotomy. Excessive damage to these tissues will not only cause postoperative bleeding, desepithelization, prolonged ecchymosis and edema, but may also result in unwanted aesthetic and unpredicted functional outcomes (2).

Isotretinoin (13 cis retinoic acid) is a vitamin A derivative used as a drug in the treatment of severe acne that does not respond to antimicrobial therapy. The daily dose of cystic acne treatment is between 0.5 and 2 mg for six months (3). However, as in hypervitaminosis A, lip dryness, decreased bone density, increased risk of fractures, liver lesions, inhibition of bone growth, increased cholesterol and triglyceride, changes in liver enzymes and alkaline phosphatase may be seen as side effects (4).

When fracture happens, bone tissue has a very precious regeneration and healing ability. Beside some other important cells and mediators, osteoclasts and osteoblasts have very crucial roles in this complicated process by synthesizing and mineralizing the bone matrix. Isotretinoin, which is used extensively in dermatology, is known to adversely affect bone healing by interrupting osteoclasts and osteoblasts during the healing process (5).

Since the age at which rhinoplasty is frequently performed is also the age that acne is frequently seen, so a person can be a candidate for both this surgery and isotretinoin therapy at the same time.

In this study, by using rabbit model, we aimed to investigate the effects of isotretinoin on lateral osteotomy that is usually performed during rhinoplasty. As far as we know, this is the first experimental study on this issue.

\section{Methods}

\section{Experimental Groups}

This study was performed between May and June 2018 at istanbul Bağcllar Training and Research Hospital Laboratory of Experimental Animals in İstanbul, Turkey. The experimental protocol was approved by the İstanbul Training and Research Hospital Local Ethics Committee of the Experimental Animals (decision no: 2018-09, date: 26.02.2018). The study was conducted in accordance with the principles of the European Community guidelines on the use of laboratory animals. A total of 12 adult, male New Zealand white rabbits weighing approximately $3-4 \mathrm{~kg}$ were maintained under ideal conditions of feeding and management in a room with cycles of 12 hours light and 12 hours dark, with constant temperature and relative humidity (60-70\%). The rabbits were divided into two groups ( $n=6$ each) designated as the experimental group as group 1 and the control group as group 2 in order to evaluate the effect of oral isotretinoin on bone healing in the early and late post-operative phases of osteotomy.

\section{Drug Administration}

İsotretinoin (Roaccutane(C), Roche) is an lipid-soluble drug. Therefore, each capsule (Roacuttane $10 \mathrm{mg}$ ) was divided in a dark room and $1 \mathrm{mg}$ dosage of drug was diluted in $10 \mathrm{~mL}$ olive oil $(0.1 \mathrm{mg} / \mathrm{mL})$. Transfer of drug was made with a black, covered box to avoid light. The mixture was given to group 1 on the day of surgery and following every morning by oral gavage by $1 \mathrm{~mL} / \mathrm{kg}$ dosage for four weeks until euthanasia. Group 2 was used as control group in which only oral olive oil was given.

\section{Surgical Procedure}

The rabbits in all groups were anesthetized with xylazine hydrochloride $10 \mathrm{mg} / \mathrm{kg}$ (Rompun, Bayer Drugs, İstanbul, Turkey) and $50 \mathrm{mg} /$ $\mathrm{kg}$ ketamine hydrochloride $59 \mathrm{mg} / \mathrm{kg}$ (Ketalar, Eczacıbaşi) Drugs, İstanbul, Turkey). Nasal dorsal skins were draped with povidone-iodine solution and shaved. After infiltration with 1\% lidocaine and 1:100.000 epinephrine mixture (Jetokaine(C), a vertical midline nasal dorsum skin incision with $5 \mathrm{~cm}$ diameter was made through the periosteum. Continuous osteotomy was performed starting from the distal end of the nasal bone and extending to the nasal bone radius using a $4 \mathrm{~mm}$ osteotome without guide. At the end of the surgery, the incised skin was sutured and closed. All rabbits were euthanized after four weeks by intracardiac pentobarbital injection. The nasal bones of the rabbits were resected from the bilateral frontal process of the maxillary bone and separated from the nasal spindle of the frontal bone. The specimens were fixed with $10 \%$ buffered formaldehyde. Hematoxylin-eosin was used for staining. Bone healing was classified according to the grading described by Huddleston et al. (6) Fracture-healing phases in each specimen was quantified with use of a scale that assigns a grade based on the relative percentages of fibrosis, cartilage formation, woven and mature bone development in the callus (6). $4 \mu \mathrm{m}$ sections were taken. Using a microscope ( $\mathrm{B} \times 51$ Japan), histological grading was performed. The grading was as follows: grade 1-fibrous tissue, grade 2-fibrous tissue with less cartilage formation, grade 3-fibrous tissue and cartilage are in the same amount, grade 4-cartilage tissue only, grade 5-predominantly cartilage and less amount of woven bone, grade 6-equal amount of cartilage and immature bone development, grade 7-more as immature bone and less cartilage, grade 8-totally immature bone, grade 9-predominantly immature bone and less amount of mature bone and grade 10-mature (lamella) bone.

\section{Statistical Analysis}

All analyses were conducted using SPSS 15.0 for Windows (SPSS Inc., Chicago, IL, USA). Correlations between categorical variables were assessed using the Pearson $\chi 2$ test and chi-square test. $\mathrm{P}<0.05$ was considered statistically significant.

\section{Results}

Grade 1 bone healing was observed in four samples (66.7\%) and grade 2 bone healing was observed (Figure 1) in two samples (33.3\%) in the study group. In the control group, three samples (50\%) had grade 2 bone healing and the remaining three samples (50\%) had grade 3 bone healing (Figure 2). The difference between the groups was statistically significant $(p=0.027)$ (Table 1). 


\begin{tabular}{|c|c|c|c|c|}
\hline & Grade 1 & Grade 2 & Grade 3 & \multirow{4}{*}{$p=0.027$} \\
\hline Study group & $4(66.7 \%)$ & $2(33.3 \%)$ & - & \\
\hline Control group & - & $3(50 \%)$ & $3(50 \%)$ & \\
\hline Total & 4 & 5 & 3 & \\
\hline
\end{tabular}

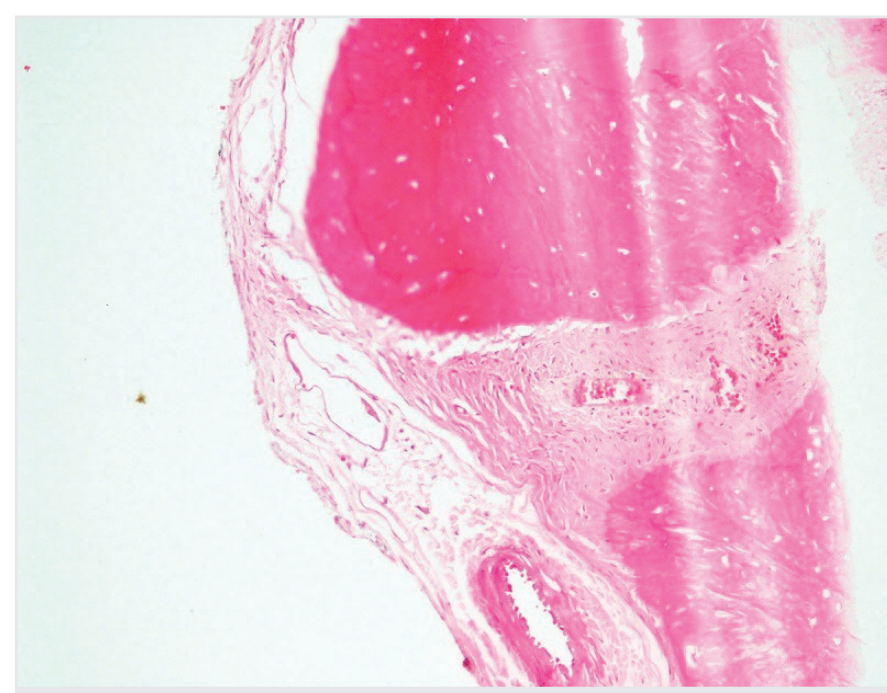

Figure 1. Grade 2 bone healing of the rabbit nasal bone; fibrous tissue is dominant with respect to cartilage tissue (hematoxylin-eosin, x100)

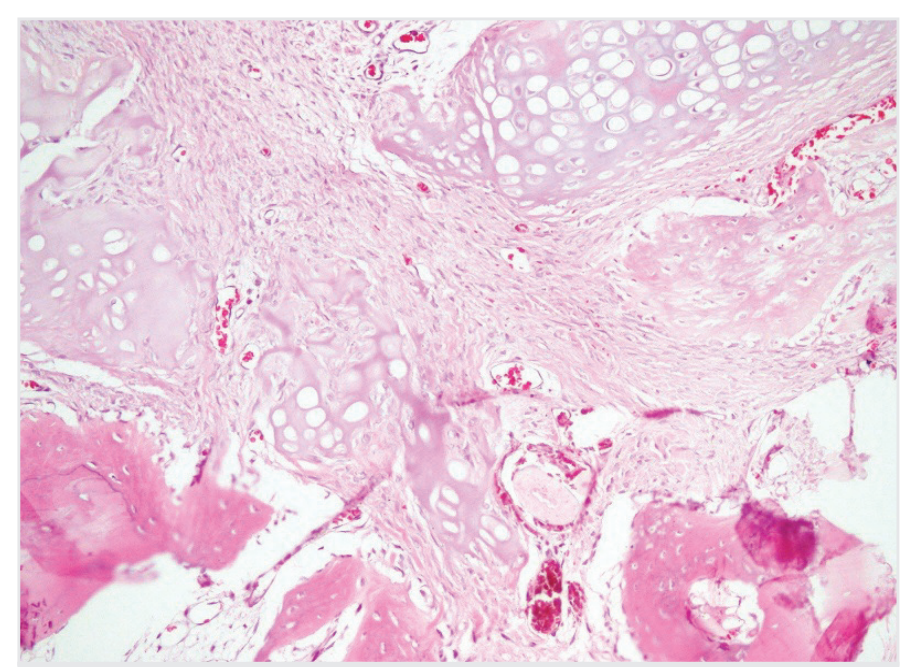

Figure 2. Grade 3 bone healing of the rabbit nasal bone; fibrous tissue formation is almost equal to cartilage tissue formation (hematoxylin-eosin, $\mathrm{x} 100)$

\section{Discussion}

Kindmark et al. (7) reported that inhibition of the release of markers that provide bone turnover and calcium regulation at the beginning of isotretinoin treatment was inhibited and that this effect was reversible in the first 14 days despite the continuation of treatment (7). While the mechanism of action of isotretinoin is not fully understood, it is believed that this drug affects the cellular differentiation, growth, morphogenesis and apoptosis, controls tumor growth and modifies cellular cohesiveness. Isotretinoin reduces the size and activity of the sebaceous glands and produce a wound-healing-like pattern followed by repair and remodeling of the skin $(8,9)$. Nishio et al. (10) reported decreased inflammatory cells infiltrating large medullary areas, growth factors and fragmented thin bone formation in external retinoic acid given animals; which pointed out that isotretinoin had a negative effect on bone formation. Similar to this, we found that nasal bone healing was adversely affected in rabbits with isotretinoin treatment.

On the contrary, the rate of new bone formation in calvarial defect of the daily retinoic acid-treated group was reported to be higher than in the untreated group in a study performed on rats (11). Similar to this study, Kamm (12) reported that synthetic isotretinoin accelerated bone repair in their animal studies. Bergoli et al. (13) investigated the formation of new bone in the cavity formed after tooth extraction in a study conducted in 32 rats. In this study, new bone formation was reported to be faster in the isotretinoin-treated group on days $7,21,28$ and 90. However, Valentic et al. (14) and Frankel et al. (15) reported higher rates of cortical and medullary bone resorption in long bones after giving high doses of vitamin A in rats. Similar to that, we observed grade 1 bone formation in four samples and grade 2 bone formation in two samples in the isotretinoin treated group in our study, which suggests that vitamin A might have a negative effect on bone healing.

The limiting feature of this study was that the number of rabbits was low and bone healing was not observed at different time periods.

\section{Conclusion}

Although there are studies reporting that isotretinoin has a positive effect on bone healing in the literature, we observed opposite results. Therefore, we think that more experimental and clinical studies are needed to clarify this effect.

Ethics Committee Approval: The experimental protocol was approved by the İstanbul Training and Research Hospital Local Ethics Committee of the Experimental Animals (decision no: 2018-09, date: 26.02.2018).

Informed Consent: Informed consent was not obtained due to the study is an animal experiment.

Peer-review: Externally peer-reviewed.

Author Contributions: Surgical and Medical Practices - Ş.Ö., H.D.T., F.E.; Concept - S..Ö.; Data Collection and/or Processing - S..Ö.; Analysis and/ or Interpretation - H.D.T., F.E.; Literature Search - H.D.T., F.E.; Writing Manuscript - Ş.Ö., H.D.T.

Conflict of Interest: No conflict of interest was declared by the authors.

Financial Disclosure: The authors declared that this study received no financial support.

\section{References}

1. Lee HM, Kang HJ, Choi JH, Chae SW, Lee HS, Hwang SJ. Rationale for osteotome selection in rhinoplasty J Laryngol Otol 2002; 116: 1005-8.

2. Becker DG, McLaughlin RB Jr, Loevner LA, Mang A. The lateral osteotomy in rhinoplasty: clinical and radiographic rationale for osteotome selection. Plast Reconstr Surg 2000; 105: 1806-16.

3. Scheinfeld N, Bangalore S. Facial edema induced by isotretinoin use: a case and a review of the side effects of isotretinoin. J Drugs Dermatol 2006; 5 : 467-8. 
4. Azulay DR, Azulay-Abulafia L. Isotretinoin-associated granulation tissue treated with occlusive corticosteroid tape. J Am Acad Dermatol 1985; 13 :837.

5. Rodan GA. Introduction to bone biology. Bone 1992; 13: 3-6.

6. Huddleston PM, Steckelberg JM, Hanssen AD, Rouse MS, Bolander ME, Patel R. Ciprofloxacin inhibition of experimental fracture healing. J Bone Joint Surg Am 2000; 82: 161-73.

7. Kindmark A, Rollman $\mathrm{O}$, Mallmin $\mathrm{H}$, Petrén-Mallmin $\mathrm{M}$, Ljunghall S, Melhus $\mathrm{H}$. Oral isotretinoin therapy in severe acne induces transient suppression of biochemical markers of bone turnover and calcium homeostasis. Acta Derm Venereol 1998; 78: 266-9.

8. Bergoli RD, Chagas Junior OL, de Souza CE, Vogt BF, de Oliveira HT, Etges A, et al. Isotretinoin effect on alveolar repair after exodontia-a study in rats. Oral Maxillofac Surg 2011; 15: 85-92.

9. Rademaker M. Isotretinoin: dose, duration and relapse. What does 30 years of usage tell us? Australas J Dermatol 2013; 54: 157-62.
10. Nishio C, Rompré P, Moldovan F. Effect of exogenous retinoic acid on tooth movement and periodontium healing following tooth extraction in a rat model. Orthod Craniofac Res 2017; 20: 77-82.

11. de Oliveira HT, Bergoli RD, Hirsch WD, Chagas OL Jr, Heitz C, Silva DN. Isotretinoin effect on the repair of bone defects-a study in rat calvaria. J Craniomaxillofac Surg 2013; 41: 581-5.

12. Kamm JJ. Toxicology, carcinogenicity, and teratogenicity of some orally administered retinoids. J Am Acad Dermatol 1982; 6: 652-9.

13. Bergoli RD, Chagas Junior OL, de Souza CE, Vogt BF, de Oliveira HT, Etges A, et al. Isotretinoin effect on alveolar repair after exodontia-a study in rats. Oral Maxillofac Surg 2011; 15: 85-92.

14. Valentic JP, Elias AN, Weinstein GD. Hypercalcemia associated with oral isotretinoin in the treatment of severe acne. JAMA 1983; 250: 1899-1900.

15. Frankel TL, Seshadri MS, McDowall DB, Cornish CJ. Hypervitaminosis A and calcium-regulating hormones in the rat. J Nutr 1986; 116: 578-87. 